KAWISTARA

VOLUME 3

No. 2, 17 Agustus 2013

Halaman 117-226

\title{
RELIGIOUS LEADER AND CHARISMATIC LEADERSHIP IN INDONESIA:THE ROLE OF KYAI IN PESANTREN IN JAVA
}

\author{
Ferry Muhammadsyah Siregar \\ Inter-Religious Study Universitas Gadjah Mada \\ Email:ferry.siregar99@yahoo.com \\ Nur Kholis Setiawan \\ Universitas Islam Negeri Sunan Kalijaga Yogyakarta \\ Robert Setio \\ Universitas kristen Duta Wacana Yogyakarta
}

\begin{abstract}
ABSTRAK
Tulisan ini membahas tentang peran kyai di pesantren di Jawa dengan fokus pada peran-peran pemimpin agama (kyai) di pesantren serta menggunakan konsep dan teori Max Weber tentang kepemimpinan agama dan karisma. Tulisan ini menggunakan data kualitatif untuk analisis bahan yang dikumpulkan dari pengamatan dan penelitian kepustakaan. Penelitian ini menemukan bahwa struktur dan pola kepemimpinan kyai dalam pesantren yang masih kuat di mana kyai diposisikan sebagai tokoh utama. Hal ini dapat dilihat pada bagaimana seorang kyai membangun peran strategis sebagai pemimpin nonformal dalam masyarakat melalui komunikasi yang intensif dengan masyarakat. Karisma kyai juga memperoleh dukungan rakyat karena stabilitas moral dan kualitas keimanan. Proses ini pada awalnya dimulai dari kelompok terdekat sekitar pesantren dan kemudian menyebar secara luas.
\end{abstract}

Kata Kunci: Pemimpin Agama, Kepemimpinan Karismatik, Karisma, Peran kyai, Pesantren.

\begin{abstract}
This paper discusses on the role of the kyai in pesantren in Java. It addresses on the roles of religious leader in pesantren. It applies Max Weber's concept on religious leadership and charisma. It uses qualitative data for analysis of materials collected from observations and library research. This research finds that the structures and patterns of leadership and power of Kyai within pesantren are strong in which kyai is positioned as the main figure. It can be seen on how a kyai build his strategic role as the non-formal leader in society through intensive communication with the people. The charisma of a kyai also gains people's support, to some extents, caused by his moral stability and faith quality. This process at first starts from the nearest group around the pesantren and then spread out to distant places.
\end{abstract}

Keywords: Religious Leader, Charismatic Leadership, Charisma, Role of Kyai, Pesantren. 


\section{INTRODUCTION}

In the history of Islam in Indonesia, According to Martin van Bruinessen (Marschall, 1994: 121-145), the pesantren is not the only institution of Muslim religious education, and the tradition it embodies is only one out of several tendencies within Indonesian Islam. Modernist, reformist, and fundamentalist currents emerged partly in opposition to it, and to some extent developed into rigid traditions themselves. One of Indonesia's great traditions is embodied in the Javanese pesantren. The main goal of these institutions is the transmission of traditional Islam.

The term 'kyai' in Javanese language has more than one meaning. It identifies things as well as men, measured by their special characteristics. For example, it is said that a person (empu) is powerful if he can put his power into his own weapon (keris). That keris is called kyai (Ziemek, 1986: 55). This kind of powerful weapon is always adored as the source of spiritual power (heirloom). It is also related to the loss of political power also because the owner has ignored rituals to keep the power embodied (Moebirman, 1979: 34).

Aside from giving predicate to weapons and heirlooms, in the context of Javanese culture, kyai title is also given to men who are elderly, wise and respected. Even with the spread of Christianity, the term is still used to refer to some natives (Javanese) Christian missionaries, in order to distinguish it from the Western missionaries (Dirdjosanjoto, 1999: 20).

Some Indonesians refer the kyai as ulama. This word is actually the plural form of the Arabic word alim which means a knowledgeable person. Through common usage in Indonesia, the word ulama grew to signify a high-level kyai, even though this is a grammatical misuse of the Arabic word (Dhofier, 1994: 63). A kyai is not a cleric in the same way as a priest or a monk in Buddhism. There is no governing body that ordains or authorizes a kyai. Likewise, no organization can defrock a kyai or remove him from his position. The reason is that a kyai has his position and authority because people listen to what he says (Lukens-Bull, 2005: 96-97).
In Java, the most essential characteristics for a pesantren is the existence of a kyai. Basically, a kyai is an honorable name for a person who possesses Islamic knowledge. A kyai usually is the initiator of the establisment of a pesantren in which he must lead the pesantren and become the policy and decision maker in it. Kyai is the founder of the pesantren in common. Martin van Bruinessen wrote:

"Highly motivated students went from pesantren to pesantren, studying in each the texts in which its kyai was specialised. After a few pesantrens in Banten, they would go on to pesantrens in Bogor, Cianjur, Cirebon, Central or East Java and finally, if their families could afford it, to Mecca, the most prestigious centre of Islamic learning. The pesantrens were typically (although not uniquely) located in rural districts, away from the major roads. Their geographical isolation symbolised, as it were, their ideological distance from the state. The pangulu, as a state official, and the independent teacher, the kyai, were two contrasting types, in Banten as well as elsewhere in Java" (van Bruinessen, 1995: 165-200).

This paper discusses on the roles of the kyai of pesantren and how the charismatic leadership functions in religious institution like pesantren.

\section{DISCUSSION \\ Religious leader and Charisma}

Religiosity or religious level is the level of knowledge, confidence, execution and appreciation of someone's religion to what he or she believes in, or an attitude of submission to a power beyond themselves realized and believed in daily activities and behaviors that covers five aspects, namely the religious beliefs (ideological), religious worship or ritual (ritualistic), religious knowledge (educational), living (experiential), and the consequence of religious practice (consequential) (Abdullah et al, 2008: 87, Anchok and Suroso, 2005).

Religious knowledge is knowledge about religion that covers various dimensions. Religious experience is a feeling experienced 
by religious people, such as a sense of calm, peace, happiness, gratitude, obedience, obey, fear, regret, repent, and others. Religious practice is the actualization of religious doctrines experienced by individuals. It forms kind of attitude, speech, and behavior or action. In fact those dimensions are not completely existed in a person, while the attitudes, words and actions are not always at the instigation of religious teachings. Religious belief is a theological perspective of religious doctrines that enter and grows in human being since every religion has to maintain a set of beliefs in which its adherents are expected to obey (Abdullah et al, 2008: 87; Ancok and Suroso, 2005).

Religious leaders within the society are sometimes recognized as charismatic leaders. They are leaders who have the ability to affect people with certain advantages. Someone is said to be the charismatic leader when his leadership came from extraordinary powers which is termed as the charismatic authority. This type of leadership is based on a person's psychological identification with others. The meaning of identification is an individual emotional involvement with another individual that ultimately the fate of their own deals with others. For the followers, the leader is the hope for a better life; he was a savior and a protector (Baharuddin, 2007:33).

Power is distributed in all social relations and it cannot be reduced to a building and the determination of centralized economic or a legal and judicial character. But the power may form a capillary isolation that exists in the whole network of social order. Furthermore, power has an impact to the formation of forces, making them to grow and organizing them rather than hinder and making them surrender or destroy (Foucault, 1980: 136). Religious leaders build and maintain the existence of their influence in the community as they maintain and build power through social relations.

Charisma and the status of religious leaders grow up along with the increasing number of their Jama'ah (followers) or students who started attending the pengajian (religious lecture by kyai/ustadz). It is held not only in pesantren, but also in other villages once a week or once a month, and sometimes once in three or six months. Additionally, religious leaders also often get invited to give lectures in special events such as maulid event, the Islamic new year, Isra 'Mi'raj and other religious events and festivals. The same thing also happens in the pesantren Ihya'ussunnah and Mu'allimin in which ustadzs often get invited to give religious lectures in special moments. Pesantren Krapyak also holds the khataman and haul of the kyai. In these events, there are many santris, alumni, and parents come and gather to celebrate. The khataman is the graduation event for students who completing their memorizing of the Quran. The haul is the event to remember death anniversary of the kyai.

Most of kyais have their own pesantren that serve as a religious home-base for his religious preaching and teaching activities. Gradually, pesantren organizes formal teaching equipped with classrooms, student dormitories, and a curriculum, and other religious instructions. Pesantren attracts students from within and outside the village. Some of them live (mondok) in the pesantren for study. Once they finished their education in pesantren, some of them choose to engage in religious activities such religious preaching in their hometown. This phenomenon happens in pesantren Krapyak, Ihya'ussunnah and Mu'allimin. This pesantrens also attracts the santris from their alumni who already had kind of sense of belonging to these pesantrens. They come from Java and other Indonesian islands, even from abroad.

Some of them choose to continue their studies abroad like in Mecca, Medina, and Cairo in the Middle East. They study abroad in order to get kind of religious authority and legality from well-known ulama to be the prophets' inheritants (successors-waratsat alAnbiya) when they come back into their origin villages to teach Islam. In this aspect, the pesantren alumni have become an important element in delivering religious teachings received from their religious leader to people around their areas. 
Religious leaders would have wishes to maintain theexistenceand influenceinsociety. The networks built by religious leaders become very important for religious leaders to reproduce the power. First, they maintain the tradition of learning from the successful ulama and authoritative institutions. For them, ulama are religious people whose strong religious roots, knowledge, and thoughts. Second, they establish good communication and cooperation with Syekhs in Indonesia and Middle East. It is kind symbolic legitimacy given by the ulamas in the Middle East and it gives considerable implications for strengthening the influence of the religious leaders within the community. Third, they join with other religious leaders who have a great popularity in the community. The ties are often seen in the attitude of those who raise the popularity of mutual friends in the community or in their respective congregations. For example, a kyai is often invited by other kyai to give lectures at other pesantren, and so with the others. They often invite religious leaders from other areas from other areas that are still in an alliance in their network and their organizations. Fourth, they provide recommendations for their students to continue their study to the Middle East countries such as Egypt or to other places. Besides to build a network between pesantrens, they also maintain caderization in the pesantren. Those who have completed study in the pesantren, some of them are directed to continue their studies abroad.

There are two reasons of why the Middle East Universities like Al-Azhar in Cairo are being their favorites: First, it has a similar understanding to Sunni teachings that become a main role model for most common people in line with lessons in the pesantren, Second, it is well known in the community as an educational institution who has delivered many scholars in the Islamic world, especially the religious leaders in the community. For some of pesantrens, although Islamic University of Medina gives scholarships, the kyai usually did not recommend to study there. It is because the religious affiliation is different from the pesantren's vision and mission.

In some cases, if it is not recommended by the kyai and pesantren, they will not be accepted as a teacher in pesantren. Their wishes to be a next religious leader will be rather difficult to achieve. If they become a teacher in pesantren, they are referred as a religious teacher and religious leader. If the santri does not have a clear religious basis in the future, it will be difficult to be a kyai or ustadz. In this case, the pesntren become the place to legitimize a person as religious leader. For those who have got an opportunity to teach in the pesantren, they will also be given the opportunity to deliver religious lectures in the community. Some of kyais have already received Master degree; some even have received Ph.D degree.

The influence of kyai in pesantren is highly strong. They preserve the traditional values and norms continuously. The idea of innovation is recognized in pesantren but it is so tiny and slow. In some cases, the formula of faith explained by kyai shows some progress. However, the structure of their life has put the idea of innovation aside (Dhofir, 1999: 81). It means that the progress of spiritual development in pesantren does not reflect the reality. Spiritual development in pesantren is the representation of kyai resistency to the idea of modernism and secularism in $20^{\text {th }}$ century of Java. Change, development and progress are grand narrative of modernism that tends to eliminate the micro narrative such as traditional institution represented by pesantren in the case of Islamic traditional institution.

However, the duty represented by pesantren is a continuous role. Although Snouck Hurgronje (1906 in Azra, 1996: 126) described that the condition of traditional Islam in Indonesia is static but this statement is close to myth rather than reality. Modernity does not come from the vacuum as it is a continuous development traced back to traditionalism. Pesantren is based on the idea of continuity of tradition resulting latter the change and innovation. Though, it is worth noting here that the idea of development in 
the field of religion is not easily understood.

For kyai, religious values, mission and system of social education in pesantren are much more important than the idea of modernism. Element of secularism is very much considered as a serious threat for Islamic institution. In Yogyakarta, the idea of continuity and adaptability to modernity has resulted two different tendencies: the moderate kyai and the militant one.

Pesantrens have been involved in internal problem pushing to the emergence of the idea of modernization debated among ulama. This fact has made them aware that they should be more careful in discussing the idea of modernity. The idea of gradual adaptation and selective choice are more reasonable to be applied by the kyai and ustadz as ulama. Gradually, change has taken place in pesantren influencing its system. Traditional education in pesantren that has been 500 years old is the vanguard of traditional Islam. It is a great challenge for the pesantren how to adapt to the wind of change. Some ulamas have adapted gradually to the wind of change, and some others seem to accept it in a very slow way. Pesantren has faced different level of change. In pesantren tradition, gaps have occurred between those who stand against secularism and those who adapt it (Dhofir, 1999: 110).

In an effort to establish a more modern Islamic educational institution, pesantren has not created yet a huge gap between traditionalism and modernism. To some degree, it is not required for us to redefine the principle of Islam and its doctrine which has been long considered as a big challenge. In the other words, pesantren still relies its activities on tradition above the authentic Islamic doctrine. Pesantren's influence has been maintained by the traditionalist Muslims upon those professionals such as kyai, teacher, and student of pesantren. Kyai's anxiety on the introduction of secular schools in Yogyakarta is too exaggerated. This anxiety has led directly to the maintaining of traditional Islam.

As a matter of fact, kyai anxiety has directly impact on the preservation of traditional
Islam. However, it is too exaggerated to say that the idea of secularism is purely west. According to H.A.R Gibb, in every advanced civilization, including the Islamic medieval civilization, secularism must be viewed in the level of larger scale or smaller, whether it is open or not. Indeed, the Muslim scholars themselves have contributed to the spread of secularism because in the Islamic world is mainly the influence of sufi regulations to sufism that worldly tendency among the educated people and classes are contracted. To debilitating the effect of it, the Muslim scholars have not succeeded to make up it and replace the influence of other religions in it, except to some extent that they have been working on new religious community (Gibb, 1947: 50-51).

\section{The Teacher, the Owner, and the Founder of Pesantren}

Generally, kyais is owner of the pesantren. They possess pesantren physically and spiritually in the sense that that ownership is seen as well as felt in the heart. Kyai ownership of the pesantren has allowed him a great deal of autonomy to run the pesantren. Practically, kyai is helped by a team consists of teachers (asatidz) and staff. But it does not affect his autonomy in managing the pesantren.

Pesantrens were usually owned by individuals who had studied for years in some parts of the Arab world especially Mecca and Cairo. Such individual owners of pesantrens are described as belonging to families that already enjoyed some religious prestige while others were bright young men who could make the voyage to Mecca due to patronage whereas others again supported themselves by engaging in trade (Bruinessen in Noor, 1998: 117).

Generally speaking a pesantren is usually owned by a kyai who is assisted in its running by some of his senior students and relations. This dimension of the ownership of the pesantren explains why the pesantren is an important part of the kyai's life. This is so in view of the fact that the pesantren, as noted earlier, serves as a medium through which 
he spreads his message and influence through his teaching, and da'wah activities (Hasyim et.al, 2011: 97).

Pesantren offered religious education to students or santri centered on a respected religious teacher or kyai. A kyai who earned a reputation as a person of great wisdom and high moral standing would attract santri from the local area as well as from further afield. Certain kyai were also considered to be experts in particular traditional religious texts, and students would often move from pesantren to pesantren seeking specific knowledge of the texts these kyai had mastered. Because of this knowledge and high moral standing, kyai were highly respected not only within the pesantren but also within the community more broadly: in many rural communities, the local pesantren was the centre of religious life and the kyai had, significant authority on religious matters.

Kyai is usually perceived as a person who possesses an extraordinary knowledge. Therefore, he could be perceived as an elite class different in many ways from the ordinary people. Kyai obtained their knowledge through various ways. Some kyai have learned in various pesantren and some others learned directly from their father. Kyai specialization is the basis on which the coming students based their choice to seek the knowledge, or 'ngelmu'.

One of kyai specialization is capability to understand the Qur'an. They have an authority in this field due to their broad knowledge in Arabic. Their broad knowledge of Arabic gives them a credit point on the eyes of their students. By mastering Arabic, kyai have an access to the first source of Islam which is written in Arabic, including the Qur'an. It is this Arabic capability that made a kyai recognized by their students. Through this language, kyai are capable of understanding the content of the Qur'an transmitted from the salaf.

Students' recognition on kyai legitimacy as the source of knowledge is also supported by kyai integrity. Knowledge cannot be separated from personal integrity. Hence, both knowledge and moral integrity are the very basic capital of kyai in order to be recognized by students.

Kyai is regarded as a capable person of teaching the lssons to his students. However, regarding the way kyai teaches, the title of 'guru' (teacher) for kyai is different from the teacher of Qur'an recitation. The concept of guru to call kyai is rather an analogy of guru who teaches at the schools. Kyai's first commitment is teaching Islamic doctrines to his students. If non-Islamic things found in pesantren, it will be modified in order to be fit with Islamic principle. In doing so, kyai employs various ways, such as adapting local tradition in delivering Islamic values and doctrines.

Kyai is regarded as the source of knowledge and integral element of intellectual tradition in pesantren. Though intellectual traditions in pesantren are varied, the role of kyai is significant in synthesizing the Islamic tradition and scientific one. Based on fundamental spirit of Islam, pesantren has long been synthesizing religious values and intellectual tradition by deconstructing the rigid boundary of knowledge, reason and faith as it is done by modernist. This synthesis will be an effective source to carry out a socio-cultural function with special preference to the virtue of Islam.

\section{The Keeper of Islamic Tradition and Culture}

Pesantren has long been rooted in Indonesian society due to its spiritual function. Pesantren is representative of Indonesian culture as well as cultural Islam. Hence, pesantren and its students are obliged culturally to protect Indonesian cultures. The issue of 'cultural' preservation is highly relevant for the pesantren world. Preservation of local culture is the trade mark of pesantren, and santri community has long been known as the avant garde in maintaining the culture. This fact could be traced back from the era of Wali Songo. In this regards, the cultural task of pesantren could be perceived as the expression of 'civilized Islam'. The idea of 
cultural preservation is also reflected from the intellectual tradition in pesantren.

In Java, especially Yogyakarta, education held by some pesantrens are aiming at the establishment of life orientation as 'Javanese Muslim' whose main task is to reconstruct peaceful social relation and create harmonious relation with God and nature. With regard to culture preservation, the tradition of pesantren has adapted Javanese traits. We call it 'modelling'. "The power of 'modelling' relies on its harmony with Javanese values which is characterized by maternalistic and hierarchical relation; those values have a deep root within Javanese society and culture" (Mas'ud, 2004: 10-11; Purwadi and Siregar, 2008).

In pesantren, kyai has traditionally had a great concern on social aspect. Santri community is representation of that social aspect. Traditionally, pesantren management has a preference on social approach and made it as the priority relating to students' problem and needs. This fact reminds us to Durkheim theory on the basic function of religion as a means of social cohesiveness.

Pesantren also plays an important role in maintaining social cohesiveness by allowing students from various social class and ethnic groups. This social function is highly needed for the future of Indonesia. However, this function should be supported by empowering communal life. In the other words, pesantren as an educational institution could be functioning to strengthen the brotherhood; pesantren emphasizes feeling of togetherness (Turner, 2003: 92).

Social role played by pesantren will be in line with the future of Indonesian society due to various reasons, those are: (1) The character of pesantren contains of social fragmentation, capitalization and spirituality erosion, (2) Social cohesion is responsibility of religion. Therefore, kyai and their pesantren could take a role to build it, and (3) Pesantren as religious institution provides social service. Therefore, pesantren could be a good place for those who have problem socially, psychologically as well as physically. Pesantren is an institution aiming at various goals; in addition to its traditional role as an Islamic social institution, it also provides traditional medicines and offers a consultation for daily life problem.

Social service provided by pesantren shows the willing of kyai to protect their status, tradition and characteristics. The actors of social programs run by pesantren are kyai and santri. They do it for the purpose of strengthening Islamic value within society. Social program and activities are varied among pesantren. We could observe that their effort depends on the context and capability of pesantren. Pesantren have done various efforts to solve social problem.

Pesantren in Java, for instance, offered a grant for poor students living around pesantren. Other pesantren have decided social program as the main topic of their education. A great numbers of alumni have created such kind of community for the pesantren. Though religious motives are the main reason to establish pesantren, but it is understood in a very broad way. Therefore, cultivating of trees is also perceived as part of religious activities (Wirosardjono, 1987: 112-113).

Tradition and change are two different and sometimes contradictory concepts. It represents two tensions of discourse. Traditional discourse tends to maintain authentic values of Islam; while change assumes that there is always elasticity and adaptability in culture, including religion. Snouck Hurgronye, Dutch Islamologist stated that situation of traditional Islam that seems very static, is in fact changing in a very fundamental way. Though, the change occurs gradually, slightly, and concentrated on mind, far away and non Islamic. Though they happen just in front our eye, but they are invisible for those who do not scrutinize it carefully (Geertz, 1963: 16).

\section{Kyai and Charismatic Leadership}

The charismatic leadership is based on an outstanding quality that is possessed by a person as a personal. This term is theological, since to identify personal attraction within a person, we must use the assumption that the 
quality that is possessed by a person is given by God. Weber identified that this leadership characteristics are must be had by those who become the religious leader. Someone's appearance is identified as a charisma that can be known from its physical character like shining eyes, strong voice, bold chin, and many other signs.

The charisma term also points to the personal quality, so that itcan be differentiated with many people. He is considered, even believed as to have spiritual power. The existence of someone that possess that character can be seen as a leader, that even though he does not gain any support from many people, he can still search and create a good profile to describe himself. Related to this, Max Weber stated:

"The term charisma will be applied to a certain quality of an individual personality by virtue of which he is set apart from ordinary men and treated as endowed with supernatural, superhuman or at least specifically exceptional powers or qualities" (Weber, 1966: 358).

There are three perspectives in understanding the leadership phenomena. Firstly, leadership does not concentrate on individual power, rather on the position or status he is holding. In Weber's perspective, a leadership concentrating on legal procedure is called legal authority. Normative procedure and the rights to lead should abide with legal procedures. In relation to this, Richard N. Osborn (1984: 245) stated that legal base would dominate since it concentrated on scientific rationally and efficiency. In the legal base, the authority figure dominates via legal procedure followers generally consider just. Legal authority is manifested in bureaucratic organization. A leader's responsibility in the organization is not determined by individual performance but by the procedural rules approved by community. Emotional elements are to be replaced by rational elements.

Secondly, traditional type of leadership is based on an established belief upon the sacred of old tradition. The status of a leader is determined by old customs practiced by society in any traditions.

Thirdly, leadership can be perceived as the ability within an individual. This means that in some aspect from someone has given powerful appeal and may cause other people to accept his will as something that must be followed. He is believed to have Divine guide, profane quality, and can gain mass from the society. In the perspective of Max Weber, the leadership that has the source from an incredible power is called the charismatic authority (Weber, 1966: 358). This type of leadership is based on the psychological identification from someone with other people. Identification here means that the emotional aspect will be also involved among people. To the followers, a leader is like a hope for a better life in the future and he is seen as the protector as well as a savior.

It is often that someone is considered to have charisma because many people believe that he has the power and wonderful ability and he is able to show it in front of the society. Due to that, he may often think about something unreal, do meditation to find inspiration that makes him separated from other people. Even so, a charismatic person does not need the entire characteristic to be with him. For him, the most important are the outstanding capacities that other people think about the attributes.

The followers of charismatic leaders are labile and easy to change mind. For some degree they are so loyal that they disregard their duty and are willing to pay some price to abide with their leaders. Thus, there exists, as in a family, a tight relation between the leader and his followers, and such relation is also found among followers in that particular community. This relation brings out moral obligation for the leader to direct his followers sustainably, either required or voluntarily. The leader comes out in difficult situation. In this context, the leader's advice and motivation are seen as a powerful and extraordinary, where for some degree it is considered divine, thus, the followers' 
credence upon it gets stronger and more for the belief of its ability to read everything happens to his followers. Here, that belief is known as ma'rifat among the followers of Tarekat.

Charismatic leaders usually come out in times of crisis and chaos. Such situation requires an urgent total solution to make the social condition quickly turns normal. Therefore a figure capable of solving the crisis immediately is requisite. For that reason, it is not a surprise, if a charismatic leader is close to an authoritarian leader; ignorant of general consensus, rational and legal formal, despite he might be personally democratic.

This kind of leadership is generally found in traditional society; a society which is highly homogenous; sharing the same values, belief, worldview as well as life style. The homogeneity will, in turn, create collective consciousness, sharing life style, direct relation among members of the group, as well as the inexistence of impersonal work division (Johnson, 1986: 63). This type of society is easily bound by a charismatic influence.

The followers who continuously abide with their charismatic leaders will rely on the advice, guidance and direction of their leaders. The problem is on how they will overcome their life in times when their leader is out of reach, how they preserve the leadership quality, how to inherit the individualistic charisma into the established, stable and sustainable organization. In short, the problem is on how to turn the personal capacity of the leader into mutual (communal) strength. The charismatic inheritance must, however, be institutionalized into a permanent and stable system of rules in the social system of society. The charisma which is initially personal will, in turn in certain condition be depersonalized and institutionalized (Bendix, 1962: 308-311).

This process of inheriting charisma from the main source which is personal into a bigger communal life, by Max Weber, is called 'charisma routinization'. This is meant so a leadership crisis will not last long. This movement appears to restore the leadership, so a leadership quality can be fully maintained. In a leader election process, the leader candidate should, at least, convince all group members that he already possessed the leadership quality his charismatic predecessor owned. In relation to this distinctive feature of charismatic leader, in Weber's perspective, it is not compatible with the idea of "routinization". It is even seen as a threat to the "routinization" as well as to the established structure, it is also a disruption to a rational leadership for it (rational leadership) relies more on a set of rules which are legally and officially acknowledged.

A leader will always be born, either in a small community or in a big one. This gives sign that there will be no social organization without the existence of a leader, along with the existence of those who are easy to be directed and to be influenced. Usually, the influencing part consists of those who are in minority group but they are dominant, while the influenced group is usually in the subordinate position and great in numbers, so that the concept of leadership can't be separated from the social, cultural, and political aspect (Kartodirjo, 1990: 7-9). To define leadership as an effort to direct people's behavior for reaching their aim has a meaning that a leader play an important role as the initiator in deciding the structure, condition, ideology, and its group activities (Haiman, 1971: 228; Susanto, 2007: 114).

All leaders do their leadership functions appropriate with their field, and this different field also differentiates among the leaders. In the other words, in one organization, a leadership may have the most vital role. The applied leadership model will affect the intensity of the member's involvement within the organizations plans. Even so, the leadership factor is still becoming the decisive factor to the efficient and the affectivity of one organization, and it is right to say that a leadership is about social judgment to the personality of a person related with the social system applied. This means that as 
long as the person that is called as a leader is considered by his followers to be able to fulfill the criteria that they need, then at that time he can keep the emotional relationship among his followers, and still also keep his leadership (Abdullah, 1987: 64; Susanto, 2007: 114).

The meaning of kyai in the context of modern Indonesia has experienced some transformations in the meaning, which only gives the title to the founder and the leader of pesantren that dedicates his life to Allah and spreads out as well as deepens Islamic teachings and perspectives through education. The semantic quality from the term ' $k y a i$ ' here has covered absolutely the component of traditional Javanese, including to lead the pesantren. The title is in one traditional synthesis and also covers the spiritual dimention within the society that is believed to have a spiritual power, for example, as a mystician or teacher or even the leader in one prestigious region that has a legitimation to his authority based on the people's trust.

Due to that, the kyai predicate is always related to a respected title that emphasizes on honor and admittance given voluntarily to the religious leader and local leader as the honorary symbol in the social life, and it is not related at all with any academic title that must be gained through some levels of formal education (Ziemek, 1986: 131; Susanto, 2007: 111). In this context, it is needed to state that kyai and Ulama is the title for the Islamic master that in the West literature these two terms are often misunderstood and the use is misplaced, but in fact, both term has different meaning in status and role.

In the perspective of Javanese and Maduranese society, the position of Kyai is much higher than Ulama. An Ulama with all sufficent condition in sometimes may be upgraded into a Kyai (Horikoshi, 1987: 1-3). With this term, it will only use the word "kyai" as Muslim leader recognized by the society to have charisma. Indeed, not all Kyai has a pondok pesantren. There are also cases that a kyai only teach religion form village to another village, just to deliver Islamic message to the society. To this type of Kyai, he is called Kyai Teko or Kendi. This Kyai preacher is analoged as a full of water teko, that also shares it to many people who need to drink the water. While the title given to a Kyai who has a pesantren is Kyai Sumur (Sukamto, 1999: 85-86).

\section{CONCLUSION}

The leadership of a kyai is often being identical with the attribute of charismatic leader. In this context, Sartono Kartodirjo stated that many kyai in pesantren, were and are, being the most influential figures that can shape our social, cultural, and religious life for Indonesian Muslim society (Kartodirjo, 1970: 114). The influence of kyai to his student is not only limited to when they are still in pesantren environment, but also it will long last until the rest of their life when they have already involved in the society.

The process of leadership will create figure of a leader. This name is existed when a person may have an ability to know another's behavior, possess special characteristic, and also special ability that other people may not have. If that character is related with the activity to mobilize the people, then a populist will be born, and if it is related with the government and official organization, then the office leader is emerged. If it is related with the administrative affair, then an administrator is come out. The same thing if it is related with tarekat organization, then the name of murshid is appeared, and the same happen with the title "kyai" if it is related to pesantren, even though not all kyai lead a pesantren (Susanto, 2007: 114; Sukamto, 1999: 19).

The role of pesantren and religious leader (kyai) is interesting phenomenon to be studied. The life of kyai makes pesantren have multi-dimensional functions. Kyai is not only a leader in the field of religious and ritual affairs, but he is also often asked for to solve religio-social difficulties and problems happening in society. The role of kyais is rooted in the community when their presence 
is believed to be a blessing. The existence of structures and patterns of kyai leadership in the pesantren remains sustainable. Kyai has socio-religious networks strongly related internally among pesantrens and externally to the outside of the pesantren as well.

Along with the continuously development of the communities pattern of life around the pesantren environment, the structures and patterns of leadership and power of Kyai within the surrounding community of pesantren is still has special status in which kyai is positioned as the focal character. Kyai has the role as follow: the religious leader, the owner and the founder of pesantren, the preacher, the keeper of Islamic culture, and the main teacher in the pesantren and community.

The leadership function that idealized as the embodied role to the status of kyai must be considered as a significant role, because leadership is one of important factor that affects the kyai to be succeed or failed in leading the society, in more specific context, to the institution he leads in (pesantren). Leadership is one of important factor. Without any good leader, then the organization wheel will not run smoothly. There are also other factors that able to support the achievement to the organization's goals such as the sufficient capital, correct organization structure, and the capability of human resources.

\section{BIBLIOGRAPHY}

Abdullah, I. Muhammad, Z. and Hasse, J. (Eds), 2008. Agama, Pendidikan Islam, dan Tanggung Jawab Sosial Pesantren. Yogyakarta: Penerbit Sekolah Pascasarjana UGM.

Abdullah, I. Siregar, F.M. dan Zain, M. (eds), 2008. Dialektika Teks Suci Agama: Strukturasi Makna dalam Kehidupan Masyarakat, Yogyakarta: Penerbit Sekolah Pascasarjana UGM dan Pustaka Pelajar.

Abdullah, M. A. 2000. Dinamika Islam Kultural: Pemetaan atas Wacana Keislaman Kontemporer, Bandung: Mizan.
2000. “Epistemologi Pendidikan Islam: Mempertegas Arah Pendidikan Nilai dalam Visi dan Misi Pendidikan Islam dalam Era Pluralitas Budaya dan Agama," dalam Makalah pada Seminar dan Lokakarya Ilmu Pendidikan Islam. Fakultas Tarbiyah IAIN Sunan Kalijaga Yogyakarta, 21 Pebruari 2000.

2002. In Gusmian, I. 2002. Khazanah Tafsir Indonesia: Dari Hermenetika Hingga Ideologi. Yogyakarta: Teraju.

Abdullah, T. 1987. Islam dan Masyarakat: Pantulan Sejarah Indonesia. Jakarta: LP3ES.

Ancok, D.J. dan Suroso, F.N. 2005. Psikologi Islam: Solusi Islam Atas problemProblem Psikologi. Yogyakarta: Pustaka Pelajar.

Anderson, B. 1972. Gagasan tentang Kekuasaan dalam Kebudayaan Jawa. Terjemahan Ali As'ad, Semarang: Menara Kudus.

Bendix, R. 1962. Max Weber: An Intelectual Portrait. New York: Ancor Books.

Boland, B.J. 1982. The Struggle of Islam in Indonesia 1945-1947. Leiden: E.J. Brill.

Bruinessen, M. 1990. “Kitab Kuning Books in Arabic Script Used in the Pesantren Millieu." BKI, 146.

1994. NU: Tradisi, Relasi-relasi Kuasa dan Pencarian Wacana Baru. Yogyakarta: LKiS.

1995. Kitab Kuning, Pesantren dan Tarekat: Tradisi-tradisi Islam di Indonesia. Bandung: Mizan.

.1994. "PesantrenandKitabKuning: Maintenance and Continuation of a Tradition of Religious Learning", in Wolfgang Marschall (ed.). Texts from the Islands: Oral and Written Traditions of Indonesia and the Malay World (Ethnologica Bernica, 4). Berne: University of Berne.

. 1995. "Sharia Court, Tarekat and Pesantren: Religious Institutions in the Sultanate of Banten." Archipel 50: 
165-200 in www.let.uu.nl/ taken on Monday. September 7, 2010.

1998. "Traditionalist and Islamist Pesantrens in Contemporary Indonesia." In The Madrasa in Asia Political Activism and Transnational Linkage by Noor, F. A et al., (ed.), Amsterdam: Amsterdam University Press. It's also Paper Presented in the Workshop The Madrasa in Asia Political Activism and Transnational Linkage. ISIM, Leiden, 24-25 May 2004.

Buang, S. 2007. "Madrasah and Muslim Education: It's Interface with Urbanization" in International Handbook of Urban Education by Pink, W.T and G.W. Noblit (Ed.).

Dhofier, Z. 1980. The Pesantren Tradition: A Study of the Role of the Kyai in the Maintenance of the Traditional Ideology of Islam in Java Tempe. AZ: Arizona State University Program for Southeast Asian Studies Monograph Series.

1982. Tradisi Pesantren: Studi tentang Pandangan Hidup Kyai. Cetakan Pertama, Jakarta: LP3ES.

1985. Tradisi Pesantren: Studi tentang Pandangan Hidup Kyai. Jakarta: LP3ES.

1994. Tradisi Pesantren: Studi tentang Pandangan Hidup Kyai. Jakarta: LP3ES.

Departemen Agama RI. 2008. Statistik Pendidikan Agama dan Keagamaan Tahun Pelajaran 2007-2008. Jakarta: Depag RI.

1981. Pesantren: Profil Kyai, Pesantren dan Madrasah. Jakarta: Badan Litbang Agama.

2000. Direktori Pondok Pesantren, Jakarta: Direktorat Jenderal Pembinaan Klembagaan Agama.

Dirdjosanjoto, P. 1999. Memelihara Umat: Kiai Pesantren-Kiai Langgar di Jawa, Yogyakarta: LKiS.
Gellner, E. 1969. Saints of the Atlas. London: Weidenfeld and Nicolson.

Geertz, C. 1963. Peddlers and Princes: Social Change and Economic Modernization in Two Indonesian Towns. Chicago: University of Chicago Press.

Gibb, H.A.R. 1947. Modern Trends in Islam. Chicago: The University of Chicago press.

Gilsenen, M. 1973. Saint and Sufi in Modern Egypt: An Essay in the Sociology of Religion. London: Oxford Monograph on Social Anthropology.

Hashim, R et al. 2011. “Traditional Islamic Education in Asia and Africa: A Comparative Study of Malaysia's Pondok, Indonesia's Pesantren and Nigeria's Traditional Madrasah." World Journal of Islamic History and Civilization, 1 (2): 94-107.

Horikoshi, H. 1987. Kyai dan Perubahan Sosial, Terjemahan Umar Basalim dan Andi Muarly Sunrawa. Jakarta: P3M.

1976. A Traditional Leader in a Time of Change: The Kyai and Ulama in West Java. Thesis for Degree of Doctor of Philosophy. Urbana: University of Illinois.

Lukens-Bull, R. 2005. A Peaceful Jihad: Negotiating Identity and Modernity in Muslim Java. New York: Palgrave McMillian.

Mas'ud, A. 2004. Intelektual Pesantren: Perhelatan Agama dan Tradisi. Yogyakarta: LKiS

Mansurnoor, I. A. 1990. Islam in an Indonesian World: Ulama of Madura. Yogyakarta: Gadjah Mada University Press

Moebirman, 1979. Keris and Other Weapons of Indonesia. Jakarta: Martinus Nitjhof.

Purwadi, S.J. and Siregar, F.M. 2008. "Pesantren dan Tantangan Modernitas di Indonesia," http:// ern.pendis.kemenag.go.id/DokPdf/ ern-v-04.pdf (Diakses 28 Juni 2011). 
Sukamto. 1999. Kepemimpinan Kyai dalam Pesantren. Jakarta: LP3ES.

Susanto, E. 2007. “Krisis Kepemimpinan Kiai: Studi atas Kharisma Kiai dalam Masyarakat." Islamica." Vol. 1, No. 2, Maret 2007 in http://ejournal. sunan-ampel.ac.id/index.php/ Islamica/article/viewFile/543/435 (Accessed December 1, 2012)

Weber, M. 1966. The Theory of Social and Economic Organization, Translated by Talcott Parson. New York: The Free Press.
1974. The Protestant Ethics and the Spirit of Capitalism, Translated by Talcott Parson. New York: Charles Scrbner's Sons.

Wirosardjono, S. 1987. The Impact of Pesantren in Education and Community Development in Indonesia. Berlin: Fredrich-Nauman Stiftung Indonesian society for Pesantren and Community development (P3M) and Technical University Berlin.

Ziemek, M. 1986. Pesantren dalam perubahan Sosial. Jakarta: P3M. 